\title{
"Ukuthwala" The Sexual- Cultural Practice with Negative Effects on the Personality of Adolescent Females in Africa
}

\author{
J.G. Kheswa \\ Department of Psychology, University of Fort Hare, Private Bag X1314, Alice, 5700, South Africa \\ Email: jkheswa@ufh.ac.za \\ V.N. Hoho \\ Department of Psychology, University of Fort Hare, Private Bag X1314, Alice, 5700, South Africa \\ Email:vhoho@ufh.ac.za
}

\section{Doi:10.5901/mjss.2014.v5n20p2808}

\begin{abstract}
Although some abductions are consensual and arranged, reports indicate that in forced marriages adolescent females are raped, emotionally and psychologically abused. Patriarchal attitude of parents and poverty stricken backgrounds are among factors contributing towards "ukuthwala". Drawing from gender-strain and social- exchange theories, vulnerable girls are being sold by parents for poverty relief, without considering that owing to lack of negotiation of safe sex between the girls and abductors, HIVIAIDS transmission is likely. This research paper accumulated previous research studies as a form of methodology to explore the socio-cultural influences driving males to abduct girls. The aim of this study is to caution the societies which justify the constitutionally unacceptable sexual behaviour of males because the majority of girls in forced marriages experience low self-esteem, PTSD, unprepared motherhood and develop neurotic personality. Given the findings of this research, recommendations are that anyone contravening the laws which protect the rights of women and children to education, security and integrity be imprisoned.
\end{abstract}

Keywords: ukuthwala, adolescent females, sexual abuse, HIVIAIDS, human rights

\section{Introduction}

The cultural practice of ukuthwala (forced marriage) is common in African countries and has been in existence since time immemorial (Koyana, 1980). The traditional leader chief "inkosi" Themba Mavundla, in KwaZulu- Natal, South Africa, advocates that the forced marriage is culturally accepted provided the girl has come of age and agrees to be abducted by the boyfriend (www.news24.com). The word ukuthwala means to carry and it is viewed as culturally-legitimated abduction of a woman whereby a young man will forcibly take a girl to his home to signify the intention of marriage (Makho, 2009). Drawing from the Recognition of Customary Marriages Act, both the bride and the bridegroom must consent to marriage. The age of consent is 18 years. If one of the parties is under 18 years of age, parental consent is an additional requirement to validate such marriage. If this cannot be obtained the permission of a child Commissioner, a Judge of the High Court or the Minister of Home Affairs must be sought. However, this is subject to the provisions of the Sexual Offences Amendment Act of 2007, which sets the age of consent to sex at 16.

Though the practice is culturally acceptable, young girls may be violently separated from their loved ones (family) by males who are complete strangers who force themselves on them and negatively affect their psychosocial well-being as well as their human rights (Boyden, Pankhurst \& Tafere, 2012; Maphanga, 2011). In Zimbabwean context this abduction is referred to as "musengabere" and the word directly translates to the one who carries a hyena and it refers to the practice of bride stealing In Kenya abduction is referred to as "akomari" and it is mainly practiced in the Turkana tribe and the Kisii ethnic group The man is believed to have studied the woman or the girl's daily activities including when she would go to the river to fetch water or to the forest to collect firewood. The man would then reappear with her after a while and present her to her family since the girl' family would be worried on the disappearance of their daughter (Bekker, 2007). In Rwanda, the abductor may ask the brides' parents to forgive him for abducting the daughter and offer a cow, money or other goods as a sign of restitution to his brides' family after the disappearance of their daughter (Dube, 2006).

Rembe, Chabaya Wadesango and Muhuro (2011) argue that in many traditional settings, poor families use the early marriage of daughters as a strategy for reducing their own economic vulnerability, shifting the economic burden 
related to a daughter's care to the husband's family. It becomes worse in Zimbabwe, where parents are the one arranging "kuzvarira"marriage between their daughters and old men. What is awful is that the girls are deprived an opportunity to choose their life partners. Because poor families have few resources to support their girls' education, or even to feed and clothe them, an economic gain to families in the form of a bride wealth may act as further motivation for child marriage (Konchese, 2005). Walker (2012) further goes on to say those early marriages reinforce the family's social status and consolidate economic relationships.

\section{Conceptual Framework}

This research paper is guided by social exchange theory and gender-strain theory. Social exchange theory emerges as the driving force in promoting ukuthwala in communities which uphold tradition where the girls who come from povertystricken households are by far the victims of forced marriages (Jeriphans, Kudakwashe \& Phinias, 2004). Due to impoverished circumstances of families, research indicates that parents unwittingly sent their children into forced marriages to settle family debts and as compensation (Hanzi, 2006). Although the rewards outweigh the costs, in a relationship characterized by social exchange theory (i.e. gifts for sex) forced adolescent females may feel less able to refuse sexual advances from their financial powerful sexual partners compared to those adolescents who do not practice social exchange theory because they are financially dependent (Baumeister \& Vohs, 2004). According to gender strain theory, adolescent females in sexual relationships may build up and retain feelings of resentment and develop different types of negative effect and the duration of these emotions last longer, due to the abuse they experience. These feelings results to anxiety, fear, hopelessness and depression which may be episodic (Nicole \& Miriam, 2006).

Because of poverty and patriarchal attitude, fathers in particular tend to sell their daughters. In 2009, the media reported that more than 20 Eastern Cape girls were forced to drop out of school to follow the traditional custom of ukuthwala. To date, girls as young as 13 years in the areas of Eastern Pondoland which covers Lusikisiki, Flagstagg, Bizana in South Africa, are still being robbed of their right to education and social development. (Maluleki, 2012). Rather than decreasing, statistics show that any young girls marry into on-going families as second or third wives where they face competition, related sexual, physical and emotional abuse and stress at very young age (UNICEF, 2007). Oyeke (2010) raises a concern that desperate parents, who sell their children to forced marriages, ignore the possibility that in most cases young girls are married to older men who may have already been infected with HIVIAIDS from previous sexual relationships. If the abducted girl gets married to be the second or third wife, she may suffer neglect from the senior wives and their families and this may lead them to develop what Alfred Adler refers to as inferiority complex in his theory of personality. Louw and Edwards (1997) describe patriarchy as a gender prejudice that is supported by a cultural system that gives men greater power and privilege than women. The Eastern Cape is a rural patriarchal society where men tend to have more than one sexual partner. Rape and sexual assaults become inevitable because young women find themselves in subservient position to men. In exchange for sex, when their boyfriends (often older men) pay for their school fees and provide them with gifts, the challenge they face is that of being unable to negotiate safe sex because they may be threatened, emotionally rejected and perceived as promiscuous or HIV- positive (Tsai, Morrison \& Singh, 2004

\section{Neurosis and Submissive Personality}

Because of abuse these youth experience inferiority complex and succumb to the orders which may come from the inlaws, quasi-husbands and senior wives. In this regard, the abducted girl may end up having a submissive personality, experience shame when opposing her suitor especially when opting for safe sex (Ryckman, 2008). Because of multiple forms of abuse, Karen Horney's theory of personality depicts that traumatized girl may develop neurotic trends, develop mood disorders, act impulsively, have low self-esteem and a dependant syndrome (Kercher, Ronald \& Carolyn, 2009). Sigmund Freud's psychoanalytic theory and Alfred Adler's theory concur that the consequences for a child who feels unwanted or rejected by his or her parents or adults, that may lead to insecurity, leaving them angry and deficient in selfesteem (Ryckman, 2008). On the premises of these theoretical assumptions, for fear of rejection the abducted girls may forge to be compliant to their husbands by engaging in sexual intercourse and reach climax even though there is no secretion of vaginal fluid. A study by Mswela (2009) reported that when vagina is dry inside, friction of the female genitalia may cause excoriation during penetration and increases the HIVIAIDS transmission. Dry sex for females is a condition that is the same as irritating the white cells that protect against HIV exposure and wipe the bacteria that usually protects and fight infections. This causes erosion that provides a gateway for HIV virus during sexual intercourse (Davis \& Tschunin, 2006). 


\section{Psychological Effects of Ukuthwala on Adolescent Females}

\subsection{Post-traumatic stress disorder}

One of the psychological effects of abduction on girls and young women is called Post Traumatic Stress Disorder (PTSD). Post-traumatic stress disorder is an anxiety disorder which develops after exposure to a terrifying event or ordeal in which grave physical harm occurred or was threatened. These traumatic events include violent personal assault such as sexual abuse (Comer, 2013; Swartz, de la Rey, Duncan, Townsend \& O'Neil, 2011). According to Masimanyane Women's Support Centre (2008), physical and sexual abuse of girls is on the increase and often unreported to the police.

Physical abuse is characterized by punching, kicking and punishing to inflict pain on the abducted. Some of the symptoms of the PTSD reported by girls in forced marriages are: insomnia, dysphoria, suicidal ideation, irregular menstrual periods and eating disoders (Sikkema, Hanse, Kochman, Tarakeshwar, Neufeld, Meade \& Fox, 2006). To cope with their negative moods, adolescent females may be extroverts and promote risky sexual behaviour to enhance positive moods (Wiebe, Drew \& Croom, 2010). Furthermore, they may resort to drugs and alcohol abuse which further put their lives at heightened risk of being rape (Thomas, 2012).

\subsection{Sexually Transmitted Infections and HIV/AIDS}

Although child marriage is sometimes believed to be a protective mechanism from the spread of HIVIAIDS, the truth is that early marriage can increase young girls' risks of HIV and AIDS and other sexually transmitted infections (STIS). The girl may not enjoy sex nor negotiate the use of condoms to prevent STIs such as gonorrhoea, syphilis including HIVIAIDS because it is against her will to engage in sexual intercourse (Rembe et al., 2011; Walker, 2012). According to Comer (2013) the psychological effect of lacking interest in sex is called hypoactive sexual desire disorder. Drawing from the Bill of Rights of RSA, 1996 chapter 2 section 12 (2), everyone has the right to bodily psychological integrity, which includes to make decisions concerning reproduction. But in this case, these girls are subject to physical pain and emotional trauma because they are being objectified.

\subsection{Maternal mortality and morbidity}

Another harmful consequence that is brought by patriarchal rights of parents over their daughters to older male in community before puberty is maternal mortality and morbidity (Walker, 2012). Puberty is a stage that is characterized by growing features of an adult like breasts and pubic hair for girls, and experience of menarche, a sign that female adolescents are capable of ovulating should they engage in unsafe sex with a male person (Louw \& Louw, 2007; Weiten, 2013). Due to an underdeveloped pelvis, girls who become pregnant before the age of 18 risk getting complications such as prolonged or obstructed labour, which may lead to loss of life or maternal complications such as obstetric fistula (UNICEF, 2003). There is an inextricable link between maternal mortality and morbidity, where pregnant girls as young as 10 to 14 years old being five times at risk to die during labour as compared to women aged 20 to 24 years old (UNFPA Child Marriage Fact Sheet, 2005). For example, in a research study conducted in Zimbabwe to investigate the relationship between mothers' maternal age and infant mortality, Dube (2012) found that the causal factor of infant mortality was due to adolescent mothers with a low weight gain since their pelvis bones were not fully developed to allow vaginal delivery of normal babies. Furthermore, Dube (2012) found that pregnant teenagers had a lack of insight and experience to seek medical care and skills to feed their babies.

\subsection{Mental retardation and physical deformities}

In communities which still uphold that food such as eggs, liver, kidneys and certain vegetables contributes to sexual prowess or increases sexual libido, pregnant women are not allowed to eat them. These communities are prevalent in countries including Malawi, South Africa, Zambia and Tanzania (Rembe et al., 2011). Since these foods have nutritional value, children may be born underdeveloped mentally and physically. Lack of nutritional food such as B- Complex vitamins, folic acid, selenium and proteins in one's diet especially during pregnancy may lead to mental retardation (Walker, 2012). 


\subsection{Prostitution}

If the estimates are that $79 \%$ of all the teenage girls that have been abducted across South Africa tend to involuntary prostitution at night clubs and shebeens where the conditions are exploitative (Lutya, 2010), the question is "what percentage of these vulnerable girls who have already 1. contracted HIV 2. are mothers 3 . attempted or successfully terminated pregnancy and/or 4. in multiple sexual relations for economic survival"? Lutya (2010) stated that young children involve themselves on intergenerational sex that involves two persons in different age brackets. An older man and a younger woman are said to be involved in an intergenerational sexual relationship when there is a huge gap between them (more than 10 years) this kind of relationship involves transactional sex (sex in exchange for gifts) or survival sex (an intimate relationship for economic benefit.

\subsection{Deprivation of educational opportunities}

Forced marriage violates a girl's right to a future and by doing so it perpetuates the 'feminization of poverty'. It does so by denying a girl opportunities and compromising their development in areas such as education, livelihood and personal growth (Thomas, 2009). They discontinue schooling, do farm work and become responsible for taking care of their husbands (Iyanuolo, 2008). In extreme cases, when the elder sister in marriage cannot conceive because of advanced age or is barren, the girl may be abducted and forced to discontinue schooling (Hanzi, 2006). In other words, the deprivation of education could have a negative impact on the psychological well-being since they are no ready to be mothers. Drawing from psychosocial development by Erik Erikson, abducted girls may grapple with the question "Who am I?" and may strive to achieve cognitive autonomy (i.e. making decisions and taking responsibility for these choices), behavioural autonomy (i.e. making choices regarding quality friendships, leisure time and finances), emotional autonomy (i.e. being independent of their parents and being able to exercise self- assertion and self-control) and moral or value autonomy (i.e. forming an own value system that may serve as a map for their own behaviour) (Louw \& Louw, 2007). In Mpumalanga, one of the harmful consequences of ukuthwala as a harmful cultural practice include separation of bride from family and friends, lack of freedom to interact with peers and participate in community activities and decreased opportunities for education (Juru, 2005).

\subsection{Social stigma}

Even when the abducted girl contemplates to escape, her virginity will be questioned. To avoid ostracism and social stigma, she decides to stay because even her family may treat her with contempt since she shall have disgraced the culture. In most cases, the abducted girls are raped soon after they have been taken to the abductors' houses and that contributes to avoidance of returning to the parents' homes (Thomas, 2009). Rembe et al., (2011) found that in some cases, girls stay in these empty and unfulfilling forced marriages because they have been threatened that they will experience misfortune should they run away. Supporting this is Maphanga (2011), who quoted a young man she interviewed regarding ukuthwala in South Africa saying

"As long as I have broken her virginity she will learn to love me, if she does not, I will force her to love me. Any way she will be damaged hence she will no longer be a virgin and with no dignity and self-esteem"

Comparatively, female survivors of sexual violence were found to be experiencing gastrointestinal symptoms and susceptible to reporting symptoms such as nausea, vomiting, abdominal pain and diarrhoea. Furthermore, owing to PTSD were found to be significantly more likely to think that they were fat, had sudden weight changes including substantial weight loss and symptoms of anorexia (Jina \& Thomas, 2013).

\section{Way Forward}

Culture as a way of life for people, is given a place in South African Constitution. But no culture is above the law as the cultural rights are protected subject to the Constitution. Although Section 31 of the Constitution recognises cultural rights of communities and groups, such rights should not be exercised in a manner inconsistent with any of the provisions of the Bill of Rights. Therefore girls should not be deprived of any economic, social and personal freedom by being forced to child marriages. Irrespective of the family-economic circumstance, parents should not justify their patriarchal attitude for their personal gain because Section 17 of the Sexual Offences Amendment Act of 2007 prohibits the sexual exploitation 
of children by parents and others. Parents and relatives who are found in abduction of girls may be imprisoned and face charges because of participation in Trafficking in Persons under section 71 of the Sexual Offences Act.

In conclusion, communities can help the police by reporting cases of ukuthwala at schools or any members of the church members especially to assist orphans who often become prey to male predators and relatives seeking to shun responsibility or to cash in on "ilobolo" or dowry.

\section{References}

Baumeister, R. F., \& Vohs, K. D. (2004). Sexual economics: Sex as female resource for social exchange in heterosexual interactions. Personality and Social Psychology Review, 8(4), 339-363.

Bekker, J.C. (2007). The Indomitable Ukuthwala Custom. Sage Publications:

Boyden, J., Pankhurst, A., \& Tafere, Y. (2012). Child protection and harmful traditional practices: female early marriage and genital modification in Ethiopia. Development in Practice, 22(4), 510-522.

Comer, R. J. (2013). Abnormal Psychology. Library of congress: United States of America.

Davis, A. J. \& Tchunin, V._(2006). Essentials of teaching and learning in nursing ethics. Nursing Ethics.

Dube, R. (2006). The NGO Network Alliance Project: Online community for Zimbabwean activists.

Dube, Z.B. (2012). The relationship between mothers' maternal age and infant mortality in Zimbabwe. (M.A. dissertation). University of Witwatersrand: Johannesburg.

Hanzi, R. (2006). Sexual Abuse and exploitation of the girl child through cultural practices in Zimbabwe. A Human Rights perspective. Masters Dissertation. University of Pretoria: Pretoria

Iyanoulu, A. E. (2008). The challenge of culture for rights of women in Africa: A critical analysis of the protocol to the African charter on human and people's rights on the right of the women in Africa. Masters' thesis. University of Cape Town: Cape Town.

Jeriphans, M., Kudakwashe, M., Phinias, T. (2004). Influences of culture on acquaintance rape among college students. Thesis, Zimbabwe University: Harare

Jina, R., \& Thomas, L. S. (2013). Health consequences of sexual violence against women. Best Practice \& Research Clinical Obstetrics \& Gynaecology, 27(1), 15-26.

Kercher, A. J., Ronald, M. R., Carolyn, A. S. (2009). Neuroticism, life events and negative thoughts in the development of depression in adolescent girls: Springer Science \& Business Media, Lcc

Konchese, P. (2005). Health Problems among Zimbabwe women: Harmful cultural practices. Harare.

Koyana, D.S. (1980) Customary Law in a Changing Society.

Louw, D. \& Louw, A. (2007). Child and adolescent development. University of Free State: Bloemfontein.

Louw, D. A. \& Edwards, D.J.A. (1997). Psychology: An introduction for students in Southern Africa. (2nd ed.). Johannesburg: Heinemann.

Lutya, T. M. (2010). Lifestyle and Routine Activities of South African Teenagers At Risk of Trafficked For Involuntary Prostitution. Journal of Child and Adolescent Mental Health, 22(2), 91-110.

Makho, N. (2009). Bride Abduction in KwaZulu Natal Schools \& Its Effects on Education, Agenda: Empowering women for gender equity. Masters in Gender Studies.

Maluleki M.J. (2012). Culture, Tradition, Custom, Law and Gender Equity . Potchefstroome Electroniese Regsblad, Vol.15 (1).

Maphanga, N.E. (2011). Traumatic experience of violence abduction leading to marriage.

Masimanyane, Women's Support Centre. (2008). Building the capacity of women and human rights advocates. South Africa.

Mswela, M. (2009). Cultural practices and HIV in South Africa: a legal perspective. Potchefstroom Electroniese Regsblad_vol.12 no. 4

Nicole, L. P. \& Miriam. D. (2006). Gender and general strain theory. Routledge Press: USA.

Oyeke, Y. (2010). The fangs of child marriage: saving the future generation. Women's Human Rights. Lagos.

Rembe, S., Chabaya, O., Wadesango, N., \& Muhuro, P. (2011). Child and forced marriage as violation of women's rights, and responses by member states in Southern African Development Community. Agenda, 25(1), 65-74.

Ryckman, R.M. (2008). Theories of Personality. (9th ed.). Thomson Wadsworth: Belmont

Sikkema, K.J, Hanse, N.B, Kochman, A, Tarakeshwar, N, Neufeld, S, Meade, C.S \& Fox, A.M, (2006). Outcomes from a Group Intervention to Coping with HIVIAids and Childhood Sexual Abuse: Reductions in Traumatic Stress, Aids and Behaviour. US National Institute of Health: Bethesda MD.

Swartz, L., de la Rey, C., Duncan, N., Townsend, L. \& O'Neill. (2011). Psychology: an introduction. (3rd ed.). Oxford University Press: Cape Town.

Thomas, C. (2009). Forced and Early Marriage: A focus on Central and Eastern Europe and Former Soviet Union countries with selected laws from other countries. United Nations: USA.

Thomas, J. H. (2012). Anxiety and Depression in Children and Adolescents: Assessment, Intervention, and Prevention. Springer: USA

Tsai, L., Morrison, C., \& Singh, T. (2004). The Vagina Monologues: A Theorised Understanding of its present and future role in the EE context.

UNFPA, (2008) 'Child marriage fact sheet: available at www.unfpa.org.swp/2005/presskit/factsheet/facts child marriage .htm, accessed 1 March.

UNICEF. (2003). Child Protection. An Analysis and achievements in 2003. UNICEF: New York.

UNICEF. (2007). UNICEF'S Experience in the area of Legislative reform: A review of selected countries. New York: UNICEF. 
Walker, J. A. (2012). Early Marriage in Africa-Trends, Harmful Effects and Interventions. African journal of reproductive health, 16(2), 231-240.

Weiten, W. (2013). Psychology. Themes and variations. South African Edition. Cengage Learning: Australia.

Wiebe, D.J., Drew, L. \& Croom, A. (2010). Health Psychology. (2nd ed). Wiley-Blackwell. 